\title{
Pretreatment Spirulina platensis Residue untuk Produksi Bioetanol
}

\section{Pretreatment of Spirulina platensis Residue for Bioethanol Production}

\author{
Heni Anggorowati ${ }^{\mathrm{a}^{*}}$, Indriana Lestari ${ }^{\mathrm{a}}$, Arief Budiman ${ }^{\mathrm{b}}$ and Yano Surya Pradana ${ }^{\mathrm{b}}$ \\ a Jurusan Teknik Kimia, Fakultas Teknik Industri, Universitas Pembangunan Nasional “Veteran” Yogyakarta, Jl. SWK 104 \\ (Lingkar Utara) Condongcatur, Sleman, Yogyakarta 55283, Indonesia \\ ${ }^{b}$ Departemen Teknik Kimia, Fakultas Teknik, Universitas Gadjah Mada, Jl. Grafika No.2 Kampus UGM, Yogyakarta 55281, \\ Indonesia
}

\section{Artikel histori : \\ Diterima 1 Maret 2021 Diterima dalam revisi 19 Maret 2021 Diterima 19 April 2021 Online 26 April 2021}

\begin{abstract}
ABSTRAK: Pemerintah Indonesia berusaha untuk menggurangi penggunaan bahan bakar fosil dengan mendorong adanya transisi ke sumber energi terbarukan. Bioetanol merupakan salah satu alternatif energi terbarukan yang mampu mengurangi penggunaan bensin di sektor transportasi. Bioetnaol dapat diproduksi dari spirulina platensis residu (SPR) yang masih mengandung karbohidrat yang tinggi. Untuk memaksimalkan perolehan bioethanol diperlukan proses pretreatment yang sesuai untuk memecah dinding sel SPR sehingga diperoleh glukosa yang siap difermentasi. Pada penelitian ini dilakukan tiga metode pretreatment yaitu ultrasonikasi, autoclave dan enzimatis. Pretreatment dengan ultrasonikasi dilakukan dengan ultasonicator batch $40 \mathrm{kHz}$ selama 30 menit dan menghasilkan glukosa sebesar 147,1154 ppm. Sedangkan dengan autoclave pada suhu $121{ }^{\circ} \mathrm{C}$ selama 30 menit menghasilkan glukosa sebesar $21.15385 \mathrm{ppm}$. Pretreatmen enzimatis dilakukan dengan menggunakan kombinasi enzim $\alpha$-amylase dan amyloglucosidase $(1: 0 ; 0,75: 0,25 ; 0,5: 0,5 ; 0,25: 0,75$ dan $0: 1)$ pada suhu $40^{\circ} \mathrm{C}$ selama 180 menit. Yield glukosa maksimum diperoleh pada pengguanaan enzim $\alpha$-amylase: amyloglucosidase $=$ 0,25: 0,75 yaitu sebesar $33,15 \%$.
\end{abstract}

Kata Kunci: spirulina platensis residue, ultasonikasi, autoclave, $\alpha$-amylase, amyloglucosidase

\begin{abstract}
The Indonesian government is trying to reduce the use of fossil fuels by encouraging a transition to renewable energy sources. Bioethanol is one of the renewable energy alternatives that can reduce the use of gasoline in the transportation sector. Bioethanol can be produced from spirulina plantesis residue (SPR) which still contains high carbohydrates. In order to maximize the yield of bioethanol, a suitable pretreatment process is needed to break down the SPR cell walls in order to obtain glucose which is ready for fermentation. In this study, three pretreatment methods were carried out, namely ultrasonication, autoclave and enzymatic. Pretreatment by ultrasonication was carried out with a ultasonicator batch of $40 \mathrm{kHz}$ for 30 minutes and resulted in glucose at $147,1154 \mathrm{ppm}$. While pretreatment with an autoclave at a temperature of $121{ }^{\circ} \mathrm{C}$ for 30 minutes produces glucose of $21.15385 \mathrm{ppm}$. Enzymatic pretreatment was performed using a combination of $\alpha$-amylase and amyloglucosidase enzymes (1: $0 ; 0.75: 0.25 ; 0.5: 0.5 ; 0.25: 0.75$ and $0: 1$ ) at $40{ }^{\circ} \mathrm{C}$ during 180 minutes. The maximum glucose yield was obtained by using the enzyme $\alpha$-amylase: amyloglucosidase $=0.25: 0.75$, which was $33.15 \%$.
\end{abstract}

Keywords: spirulina platensis residue, ultrasonication, autoclave, $\alpha$-amylase, amyloglucosidase

\section{Pendahuluan}

Dalam Nationally Determined Contribution (NDC) Indonesia berkomitmen untuk menurunkan emisi gas rumah kaca sebesar 29\% pada tahun 2030. Oleh karena itu, pemerintah Indonesia saat ini sedang fokus untuk menekan emisi dari penggunaan bahan bakar minyak (BBM). Salah satu rekomendasi BAPENAS 88 kebijakan rendah karbon untuk dilaksanakan periode 2020 - 2045 adalah mendorong transisi ke sumber energi terbarukan (EBT) (Sugiyono et al. 2019). Bioetanol merupakan alternatif bahan bakar yang menjanjikan untuk menggantikan bensin di sektor transportasi (Robak and Balcerek, 2018)

Bioetanol dapat diproduksi dari biomassa yang mengandung karbohidrat dalam bentuk pati maupun selulosa (Rodrigues et al., 2015). Salah satu biomassa yang mengandung karbohidrat adalah mikroalga. Mikroalga merupakan biomassa yang dinding sel nya sebagian besar

*Corresponding Author:

Email: heni.anggorowati@upnyk.ac.id 
terdiri dari karbohidrat yang dapat dikonversi menjadi glukosa sehingga dapat difermentasi menjadi bioetanol (Michelon et al., 2019). Mikroalga setelah diekstrak lipidnya akan menyisakan residu yang masih mengandung karbohidrat (Jamilatun et al, 2019). Mikroalga jenis spirulina platensis dalam kondisi kering mengandung karbohidrat 56,56\% (Rempel et al., 2018) dari hasil kultivasi yang dilakukan oleh Magro et al (2017), sedangkan spirulina platensis residue (SPR) masih mengandung karbohidrat sebesar 38,51\% (Jamilatun et al, 2017) sehingga berpotensi sebagai bahan baku bioetanol.

Karbohidrat di dalam mikroalga berupa selulosa yang terdapat pada dinding sel dan pati yang terdapat pada plastida (Velazquez at al., 2018). Karena terletak di dalam dinding sel maka konversi karbohidrat menjadi glukosa yang dapat difermentasi menjadi sangat lambat oleh karena itu diperlukan pretreatment yang bertujuan untuk memperluas bidang kontak dan melemahkan dinding sel sehingga mempermudah akses enzim pada saat proses hidrolisis (Eldalatony et al, 2015). Hammann (2019) melaporkan ada berbagai macam proses pretreatment yang dapat dilakukan untuk memecah dinding sel mikroalga diantaranya adalah secara kimia (acid dan alkali), biologi (enzim) serta pretreatment secara fisika (ultrasonikasi, microwave, autoclave). Efektifitas metode pretreatment yang digunakan akan berbeda terhadap jenis mikroalga yang berbeda.

Pretreatment enzimatis merupakan metode yang paling menjanjikan dibandingkan metode pretreatment yang lainnya (Liang et al., 2012; Demuez et al., 2015). Pada metode pretreatment ini, beberapa jenis enzim seperti amylase, sellulase, dan amyloglucosidase dapat digunakan untuk menghidrolisis dinding sel polisakarida (Shokrkar et al, 2017; Velazquez-Lucio et al, 2018). Choi et al (2010) menggunakan enzim $\alpha$-amylase dan amiloglucosidase untuk melakukan pretreatment terhadap mikroalga Chlamydomonas reinhardtii. Enzim $\alpha$-amylase dan amiloglucosidase juga berhasil menghidrolisa pati sorgum merah menjadi glukosa (Permanasari et al, 2018).

Selain pretreatment enzimatis, proses pretreatment ultrasonikasi terhadap mikroalga juga sering digunakan karena memiliki beberapa keuntungan di antaranya: mengurangi waktu ekstraksi, solvent yang dibutuhkan hanya sedikit, menghasilkan yield yang lebih tinggi dan dapat dilakukan pada suhu rendah (Luque-Garcia and Leque de Castro, 2003; Lee and Shah, 2012; Wang and Waller, 2006). Penggunaan metode pretreatment ultrasonikasi terhadap mikroalga dapat mengekstrak komponen karbohidrat terutama glukosa sehingga akan mempermudah proses fermentasi menghasilkan bioethanol (Jeon et al., 2013). Selain pretreatment enzimatis dan ultrasonikasi, pretreatment dengan autoclave juga dapat dipertimbangkan. Debiagi et al (2020) melaporkan bahwa proses pretreatment dengan autoclave mampu merilis glucose, xylose dan beberapa monosakarida dari kulit gandum.

Penelitian ini bertujuan untuk mengetahui pengaruh metode pretreatment dengan ultrasonikasi dan autoclave serta penggunaan enzim ganda ( $\alpha$-amylase dan amiloglucosidase) terhadap proses hidrolisis SPR, sehingga akan diketahui mana yang lebih efisien untuk membuka dinding sel SPR sehingga dihasilkan glukosa yang tinggi yang selanjutnya dapat dikonversi menjadi bioetanol melalui proses fermentasi.

\section{Metode Penelitian}

\subsection{Bahan}

Bahan - bahan yang digunakan pada penelitian ini adalah Spirulina platensis residue (SPR) yang diperoleh dari hasil ekstraksi Spirulina platensis (SP) Nogotirto Algae Park Yogyakarta Indonesia. Enzim $\alpha$-amylase dan amiloglukosidase yang diperoleh dari novozymes, serta reagensia Nelson, reagensia arsenomolybdat, dan larutan buffer asetat $\mathrm{pH} 4,8$.

\subsection{Alat}

Peralatan yang digunakan pada penilitian ini adalah sonicator batch dan autoclave untuk pretreatment, rangkaian untuk hidrolisis yang terdiri dari hot plate magnetic stirrer, labu leher dua dan termometer, serta centrifuge yang digunakan untuk memisahkan sampel padat dan cair setelah proses hidrolisis.

\subsection{Metode}

\subsubsection{Pretreatment ultrasonikasi dan autoclave}

Sampel SPR sebanyak 2 gram dimasukkan ke dalam 200 $\mathrm{mL}$ larutan buffer asetat $\mathrm{pH}$ 4,8 kemudian dilakukan pretreatment menggunakan ultrasonicator batch selama 30 menit, frekuensi $40 \mathrm{KHz}$ dan pretreatment dengan autoclave selama 30 menit, suhu $121{ }^{\circ} \mathrm{C}$

\subsubsection{Pretreatment enzimatis}

Sebanyak 2 gram sampel SPR dimasukkan ke dalam 200 $\mathrm{mL}$ larutan buffer asetat $\mathrm{pH} 4,8$. Kemudian ditambahkan $1 \%$ enzim $\alpha$-amylase dan amyloglucosidase dengan variasi $1: 0 ; 0,25: 0,75 ; 0,5: 0,5 ; 075: 0,25$; 0:1 v/v. Selama hidrolisis suhu dijaga konstan $40{ }^{\circ} \mathrm{C}$ dan kecepatan pengadukan $750 \mathrm{rpm}$.

\subsection{Analisa}

Setelah proses hidrolisis, sampel kemudian direndam dalam air suhu $90{ }^{\circ} \mathrm{C}$ selama 10 menit untuk menghentikan aktivitas enzim. Setelah dingin sampel dipisahkan padatan dan cairannya dengan centrifuge. Filtrat yang diperoleh kemudian dianalisis gula reduksinya dengan metode Nelson Somoygi dan HPLC untuk mengetahui jenis gula reduksinya. Sedangkan residu yang telah dikeringkan dianalisis morfologinya dengan menggunakan scanning electron microscope (SEM).

\section{Hasil dan Pembahasan}

Pretreatment yang dilakukan pada penelitian ini adalah 3 macam yaitu pretreatment secara mekanik dengan ultrasonikasi, pretreatment secara thermal dengan autoclave serta pretreatment secara enzimatis dengan 
variasi penggunaan 2 enzim yaitu enzim $\alpha$-amylase dan amiloglucosidase. Tujuan utama dari proses pretreatment adalah untuk memecah karbohidrat yang terdapat di dalam sel mikroalga menjadi monomer glukosa yang selanjutnya dapat difermentasi menjadi bioetanol.

\subsection{Pretreatment ultrasonikasi}

Ultrasonikasi merupakan salah satu metode cell disruption secara fisika yang tujuan utamanya adalah mengektraksi karbohidrat di dalam mikroalga. Selama proses sonikasi, mikroalga terkena gelombang tinggi ultrasonik sehingga tercipta gelembung kecil kavitasi di sekitar sel. Gelembung tersebut hancur dan mengeluarkan gelombang kejut yang menyebabkan karbohidrat siap untuk proses hidrolisis (Hammann, 2019).

Untuk mengetahui pengaruh pretreatment ultrasonikasi, sampel SPR dalam larutan buffer acetat $\mathrm{pH}$ 4,8 dimasukkan ke dalam ultrasonic batch dengan frekuensi $40 \mathrm{kHz}$ selama 30 menit. Hasil analisa glukosa dengan metode Nelson Somoygi dapat dilihat pada Tabel 1. Sebanyak 147.1154 ppm glukosa diperoleh setelah dilakukan ultrasonikasi selama 30 menit. Hal ini sesuai dengan hasil penelitian yang dilakukan Halim et al, 2012 yaitu menggunakan metode ultrasonikasi dengan frekuensi $40 \mathrm{kHz}$ selama 25 menit untuk megekstrak karbohidrat dalam Chlorococcum sp. Sedangkan Ferreira et al. (2016) berhasil mengekstrak karbohidrat dalam C. vulgaris, Nannochloropsis oculata, dan $S$. obliquus menggunakan metode ultrasonikasi.

Untuk mengetahui pengaruh pretreatment ultrasonikasi terhadap morfologi SPR maka digunakan analisis scanning electron microscope (SEM) seperti yang terlihat pada Gambar 1.

Dari Gambar 1b dapat dilihat morfologi permukaan sel setelah pretreatment ultrasonikasi terjadi kerusakan pada permukaan sel dibandingkan dengan tanpa pretreatment seperti yang terlihat pada Gambar 1a.

Tabel 1. Pengaruh Pretreatment

\begin{tabular}{lc}
\hline Pretreatment & $\begin{array}{c}\text { Konsentrasi glukosa } \\
(\mathrm{mg} / \mathrm{L})\end{array}$ \\
\hline Tanpa Pretreatment & 0 \\
Ultrasonikasi & 147.1154 \\
Autoclave & 21.15385 \\
\hline
\end{tabular}

\subsection{Pretreatment autoclave}

Autoclave merupakan proses pretreatment yang memanfaatkan uap panas bertekanan tinggi sehingga dapat menyebabkan dinding sel mikroalga pecah dan melepaskan komponen intraselulernya (Hammann, 2019).

Gambar 1c menunjukkan hasil SEM dari sampel yang telah dilakukan pretreatment dengan autoclave terlihat terjadi aglomerisasi sehingga menghalangi masuknya solvent, hal ini sesuai dengan jumlah glukosa yang dihasilkan dengan pretreatment autoclave yang terdapat pada Tabel 1.

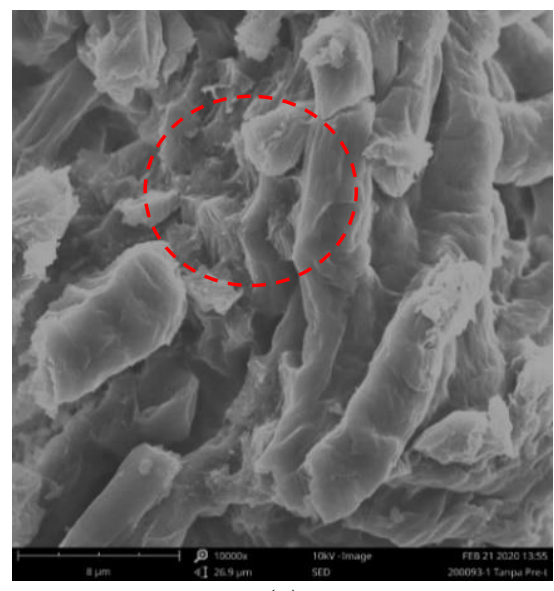

(a)

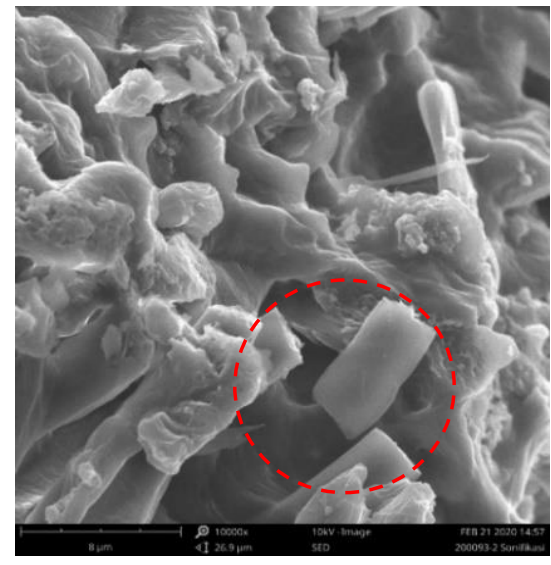

(b)

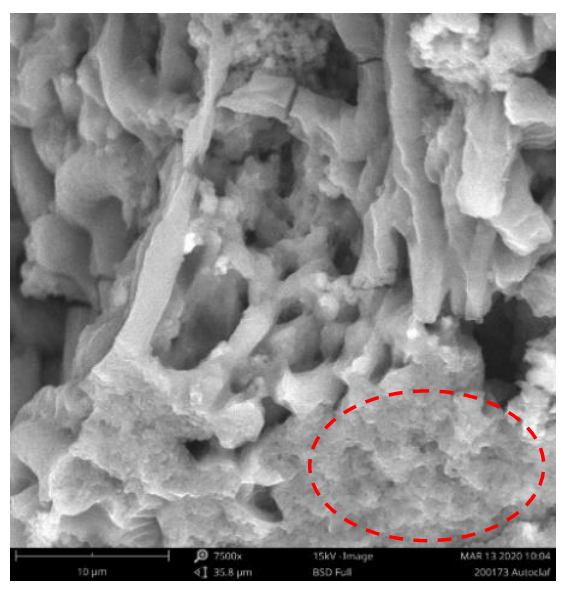

(c)

Gambar 1. Hasil SEM (Scanning Electron Microscope) pada (a) SPR tanpa pretreatment; (b) SPR setelah pretreatment ultrasonikasi; (c) SPR setelah pretreatment autoclave

Pretreatment autoclave terhadap jenis mikroalga yang berbeda efektifitasnya akan bervariasi karena memiliki struktur sel yang berbeda (Miranda et al., 2012). Oleh karena itu pretreatment autoclave harus dikombinasikan dengan metode lain seperti hidrolisis enzimatis (Hammann, 2019). 


\subsection{Pretreatment enzimatis}

Karbohidrat dalam mikroalga sebagian besar terdiri dari selulosa dan pati. Selulosa tersusun dari monomer monomer glukosa yang dihubungkan oleh ikatan $\beta-1,4$ glukosida sedangkan pati dihubungkan oleh ikatan $\alpha-1,4$ dan $\alpha-1,6$ glukosida.

Enzim amiloglukosidase dapat menghidrolisis pati sedangkan enzim amylase akan menghidrolisis selulosa. Oleh sebab itu enzim $\alpha$-amylase dan amyloglucosidase sering digunakan untuk menghidrolisis selulose dan pati yang terdapat di dalam mikroalga (Van zyl et al., 2012)

Enzim $\alpha$-amylase akan menghidrolisa pati menjadi disakarida sedangkan amyloglucosidase akan menghidrolisis lanjut menjadi monomer glukosa (Al Abdallah et al., 2016). Menurut Rempel et al (2019) hidrolisis spirulina platensis dengan menggunakan kombinasi enzim $\alpha$-amylase dan amyloglucosidase mampu menkonversi pati menjadi glucosa dengan yield $82 \%$.

Pengaruh perbandingan enzim $\alpha$-amylase dan amyloglucosidase yang digunakan terhadap yield glukosa dapat dilihat pada Gambar 2. Yield glukosa maksimum yaitu 33,15\% diperoleh pada variasi penggunaan enzim $\alpha$ amylase : amyloglucosidase dengan perbandingan 0,25 : 0,75 . Hasil ini sesuai dengan penelitian yang dilakukan Hargono et al (2018) yang melakukan hidrolisa pati singkong menggunakan enzim $\alpha$-amylase : amyloglucosidase $=1: 3$ dan menghasilkan gula reduksi sebesar 93, 45 g/L. Hasil terendah dengan yield sebesar 9,7 $\%$ diperoleh pada penggunaan enzim $\alpha$-amylase : amyloglucosidase = 1: 0 atau hanya menggunakan enzim $\alpha$-amylase saja. Shokrkar dan Ebrahimi (2018) juga melaporkan yield glukosa sebesar 5,7 \% diperoleh pada peggunaan enzim $\alpha$-amylase tanpa adanya penambahan enzim amyloglucosidase. Hal ini menunjukkan bahwa enzim $\alpha$-amylase hanya memecah ikatan $\alpha-1,4$ glukosida.

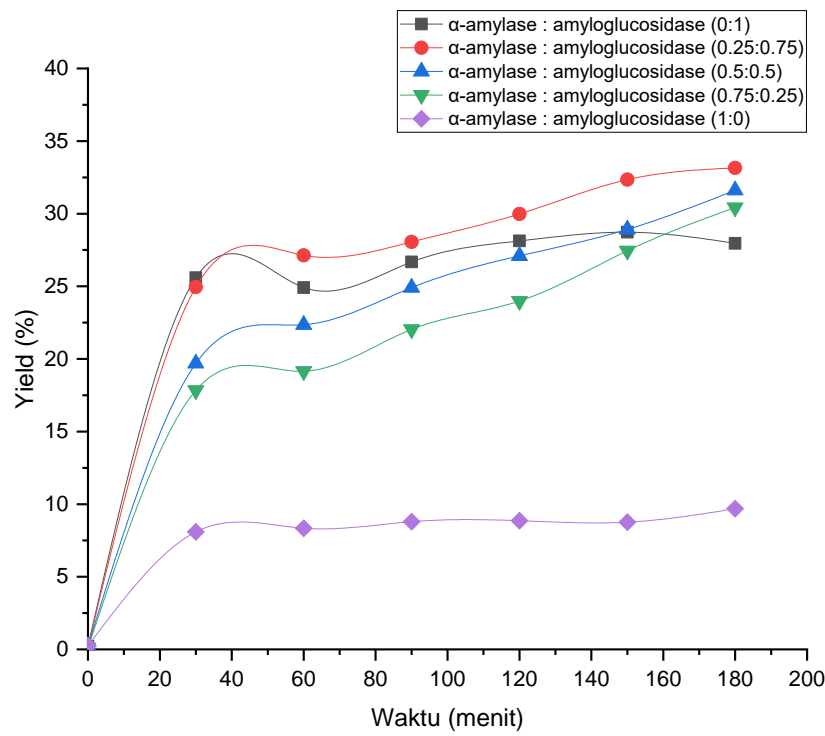

Gambar 2. Yield glukosa hasil hidrolisis SPR dengan variasi enzim

Untuk mengetahui selektifitas pengaruh enzim terhadap jenis gula reduksi yang dihasilkan, maka sampel dilakukan uji HPLC (high performance liquid chromatography) dan hasilnya dapat dilihat pada Gambar 3, 4 dan 5.

Gambar 3 menunjukkan chromatogram HPLC dari sampel dengan variasi penggunaan enzim $\alpha$-amylase: amyloglucosidase $=1: 0$ terlihat adanya spectra pada retention time 14,948 - 17,328 yang identik dengan spectra dari standar sukrosa.
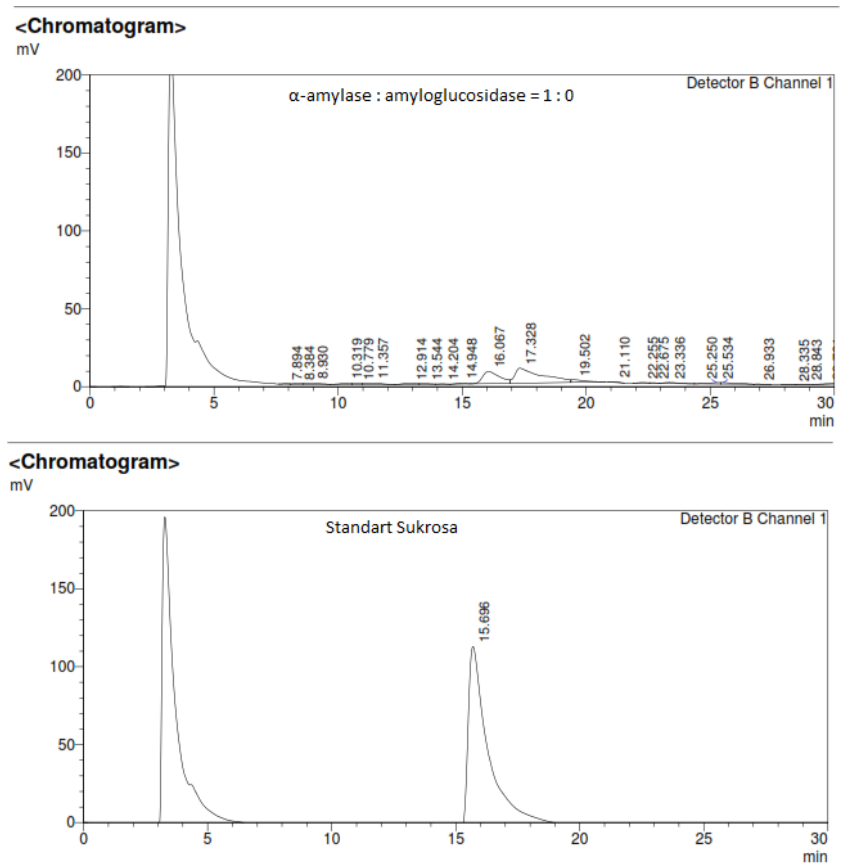

Gambar 3. Hasil analisa HPLC sampel dengan perbandingan enzim $\alpha$-amylase : amyloglucosidase $=1: 0$
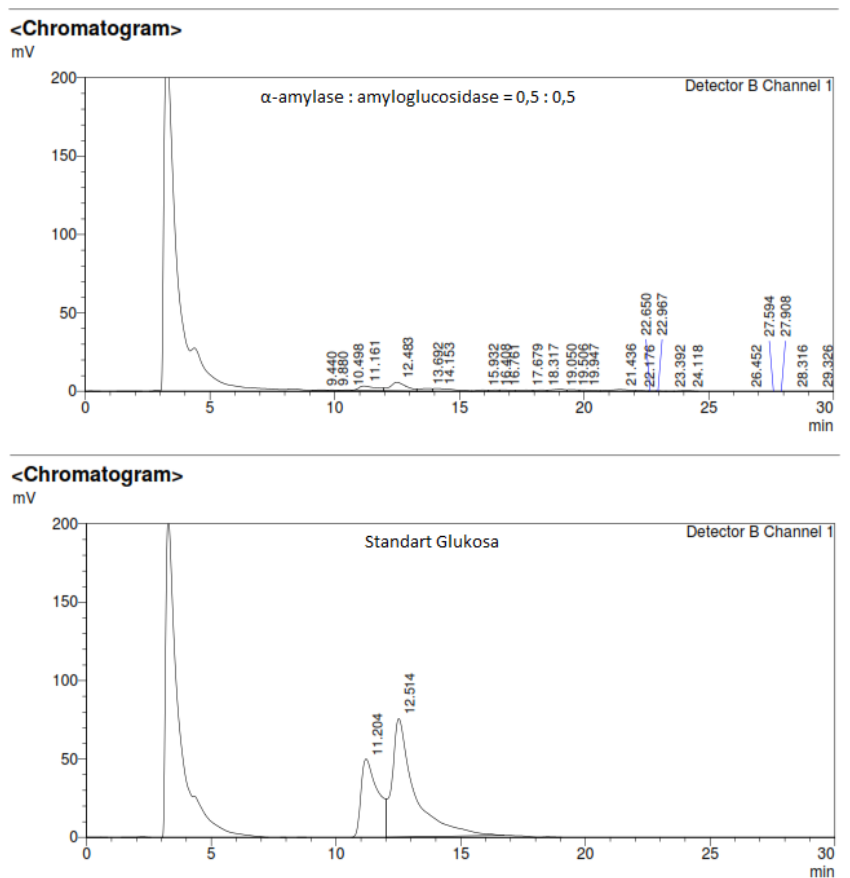

Gambar 4. Hasil analisa HPLC sampel dengan perbandingan enzim $\alpha$-amylase : amyloglucosidase $=0,5$ : 0,5 

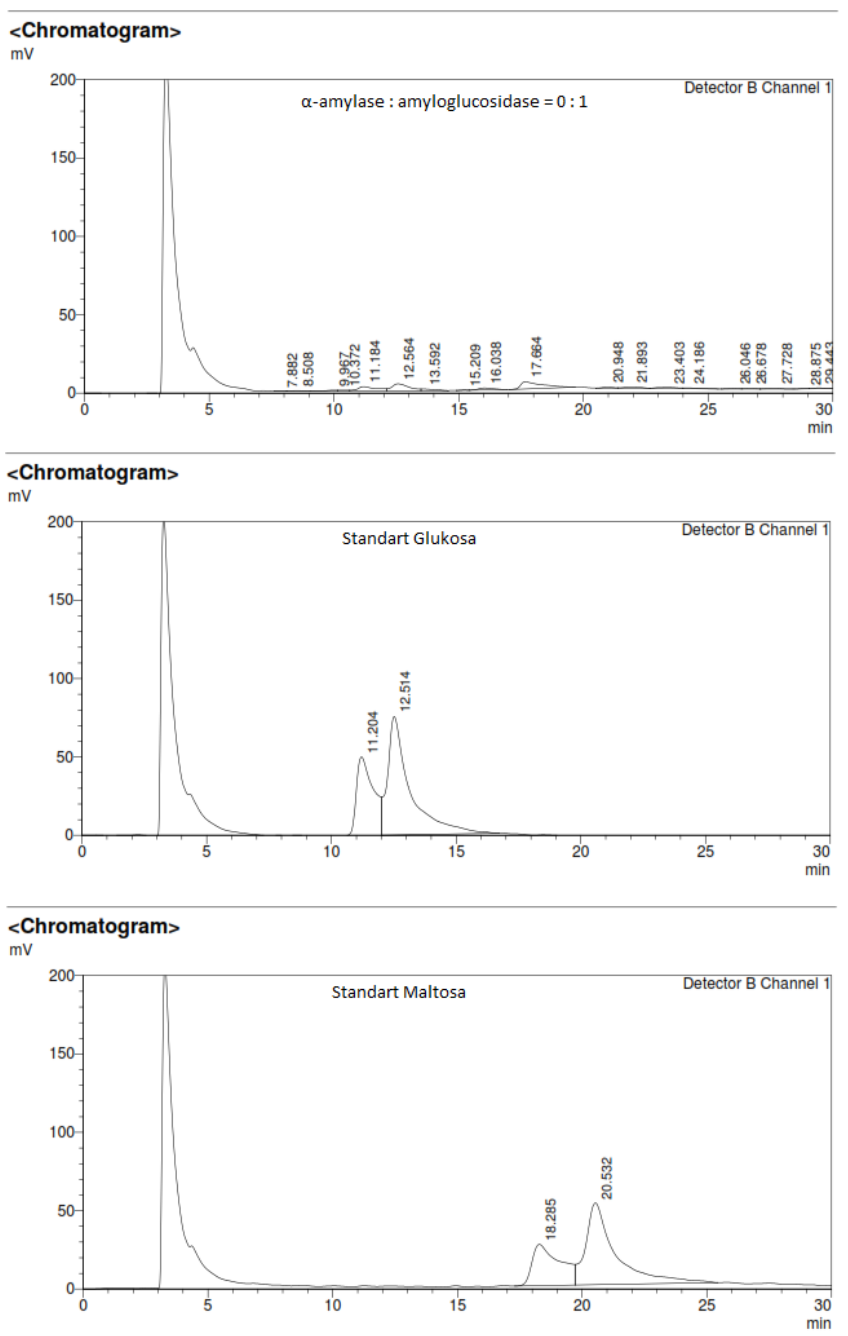

Gambar 5. Hasil analisa HPLC sampel dengan perbandingan enzim $\alpha$-amylase : amyloglucosidase $=0: 1$

Untuk chromatogram sampel dengan penggunaan enzim $\alpha$-amylase : amyloglucosidase $=0,5: 0,5$ terdapat spectra pada retention time 12,483 yang identik dengan spectra dari standart glukosa (Gambar 4). Sedangkan untuk sampel dengan pengguaaan enzim $\alpha$-amylase : amyloglucosidase $=0: 1$ dapat dilihat pada Gambar 5 . Dengan penggunaan enzim amyloglucosidase terdapat spectra pada retention time pada kisaran 11, 12, serta 17-20 yang identik dengan spectra glukosa dan maltosa. Dari analisa HPLC ini dapat disimpulkan bahwa enzim $\alpha$ amylase akan cenderung menghasilkan disakarida karena enzim ini hanya menghidrolisis ikatan $\alpha-1,4$ glukosida sedangkan enzim amyloglucosidase akan menghasilkan glukosa dan maltosa karena mampu menghidrolisis ikatan $\alpha-1,4$ dan $\alpha-1,6$ glikosida.

\section{Kesimpulan}

Pretreatment terhadap SPR untuk memecah dinding sel agar siap untuk proses fermentasi menjadi bioetanol yang paling efektif adalah menggunakan enzim dengan perbandingan $\alpha$-amylase : amyloglucosidase $=0,25: 0,75$ yang dapat penghasilkan yield glukosa sebesar $33,15 \%$. Pretreatment dengan ultrasonikasi juga dapat membantu memecah dinding sel SPR, namun kurang efektif karena hanya sehingga perlu dikombinasikan dengan pretreatment secara enzimatis.

\section{DAFTAR PUSTAKA}

Abdallah, Q., Nixon, B.T., and Fortwendel, J.R., 2016. The enzymatic conversion of major algal and cyanobacterial carbohydrates to bioethanol. Frontiers in Energy Research. Vol 4. No 36. 1-15

Choi, S.P., Nguyen, M.T., Sim, S.J., 2010. Enzymatic pretreatment of chlamydomonas reinhardtii biomass for ethanol production. Bioresource Technology. Vol 101. No 14. 5330-5336.

Debiagi, F., Madeira, T.B., Nixdorf, S.L., and Mali., S., 2020. Pretreatment efficiency using autoclave high pressure steam and ultrasonication in sugar production from liquid hydrolysates and acess to the residual solid fractions of wheat bran and oat hulls. Applied Biochemistry and Biotechnology. Vol 190. 166-181.

Demuez, M., Mahdy, A., Tomas-Pejo, E., GonzalezFernandez, C., Ballesteros, M., 2015. Enzymatic cell disruption of microalgae biomass in biorefinery process. Biotechnol Bioeng. Vol 112. No 10. 19551966

Eldalatony, M.M., Kabra., A.N., Hwang, J.H., Govindwar, S.P., Kim, K.H., Kim, H., Jeon, B.H., 2015. Pretreatment of microalgal biomass for enchanced recovery/extraction of reducing sugar and proteins. Bioprocess Biosyst Eng. Vol 39. 95-103.

Ferreira, A.F., Dias, A.P.S., Silva, C.M., dan Costa, M., 2016. Effect of low frequency ultrasound on microalgae solvent extraction : analysis of product, energy consumption and emissions. Alga Research. Vol 14. 916.

Halim, R., Harun, R., Danquah, M.K., Webley, P.A., 2012. Microalgal cell disruption for biofuel development. Applied Energy. Vol 19. 116-121.

Hammann, W.R., 2019. Method development and optimization for the recovery of carbohidrates from a microalga species of chlorella vulgaris by combined physical and chemical pertreatments. Thesis. University of North Dakota

Hargono, H., Kumoro, A.C., Jos, B., 2018. Studi kinetika hidrolisis enzimatik pati singkong: pengaruh perbandingan alfa-amilase dan glukoamilase terhadap gula reduksi. Prosiding Seminar Nasional Teknik Kimia "Kejuangan". F1. 1-7.

Jamilatun, S., Budhijanto, B., Rochmadi, R., Budiman, A., 2017. Thermal decomposition and kinetics studies of pyrolysis of spirulina platensis residue. Int Journal of Renewable Energy Development (IJRED). Vol 6. No 3. 193-201.

Jamilatun, S., Budiman, A., Anggorowati, H., Yuliestyan, A., Pradana, Y.S., Budhijanto, B., Rochmadi, R., 2019. 
Ex-situ catalytic upgrading of spirulina platensis residue oil using silica alumina catalyst. International Journal of Renewable Energy Research (IJRER). Vol 9. No 4. 1733-1740

Jeon, B.H., Choi, J.A., Kim, H.C., Hwang, J.H., Al AbouShanab, R., Dempsey, B.A., Regan, J.M., and Kim, J.R., 2013. Ultrasonic disintegration of microalgal biomass and consequent improvement of bioaccessibility/bioavailability in microbial fermentation. Biotechnology for Biofuels. Vol 6. No 37. 1-9.

Lee, S., and Shah, Y.T., 2012. Biofuel and bioenergy : processes and technologies. CRC Press. London. England.

Liang, K., Zhang, Q., Cong, W., 2012. Enzyme assisted aqueous extraction of lipid from microalgae. Journal of Agriculture and food Chemistry. Vol 60. No 47. 1177111776.

Luque-Garcia, J.L., and Luque de Castro, M.D., 2003. Ultrasound : a powerfull tool for leaching. Trend in Analitical Chem. Vol 22. 41-47.

Magro, F.G., Margarites, A.C., Reinehr, C.O., Gonçalves, G.C., Grazieli Rodigheri, G., Costa, J.A.V., Colla, L.M., 2017. Spirulina platensis biomass composition is influenced by the light availability and harvest phase in raceway ponds. Environ. Technol. Vol 22, 1-10.

Michelon, W., Pirolli, M., Mezzari, M.P., Soares, H.M., and Busi da Silva, M.L., 2019. Residual sugar from microalgae biomass harvested from phycoremediation of swine wastewater digestate. Water Science \& Technology. Vol 79. No 11. 2203-2210

Miranda, J.R., Passarinho, P.c., and Gouveia, L., 2012. Pretreatment optimization of scenedesmus obliquus microalga for bioethanol production. Bioresource Technology. Vol 104. 342-348.

Permanasari, A.R., Yulistiani, F., Purnama, R.W., Widjaja, T., and Gunawan, S., 2018. IOP Conference Series : Eart and Enviromental Science. 160. 1-6.

Rempel, A., Machado, T., Treichel, H., Colla, E., Margarites, A.C., and Colla, L.M., 2018. Saccharification of spirulina platensis biomass using free and immobilized amylolytic enzymes. Bioresource Technology. Vol 263. 163-171

Rempel, A., Sossella, F., Margarites, A., Astolfi, A., Steinmetz, R., Kunz, A., Treichel, H., Colla, L., 2019. Bioethanol from Spirulina platensis biomass and the use of residuals to produce biomethane: An energy efficient approach. Bioresource Technology. Vol 288. 121588. 10.1016/j.biortech.2019.121588.

Robak, K., and Balcerek, M., 2018. Review of second generation bioethanol production from residual biomass. Food Technology \& Biotechnology. Vol 56. No 2. 174-187

Rodrigues, C.S., Villela, H.D.M., Martins, A.P., Marques, L.G., Colepicolo, P., and Tonon, A.P., 2015. Mocroalgae for economic applications : advantages and perspectives for bioethanol. Journal of Experimental Botany. Vol 66 No 14. 4097-4108.

Shokrkar, H., Ebrahimi, S., Zamani, M., 2017. Bioethanol production from acidic and enzymatic hydrolysates of mixed microalgae culture. Fuel. Vol 200. 380-386.

Shokrkar, H., and Ebrahimi, S., 2018. Synergism of cellulase and amylolitic enzymes in the hydrolysis of microalgal carbohydrates. Biofuel, Bioproduct \& Biorefining. Vol 12. No 5. 749-755.

Sugiyono, A., Anindhita., Fitriana, I., Wahid, L.M.A., Adiarso., 2019. Dampak peningkatan pemanfaatan energi baru terbarukan terhadap perekonomian nasional. BPPT. pp 2

Van Zyl, W.H., Bloom, M., and Viktor, M.J., 2012. Engineering yeasts for raw starch conversion. Appl Microbial Biotechnology. Vol 95. 1377-1388.

Velazquez-Lucio, J., Rodriguez-Jasso, R.M., Colla, L.M., Saenz-Galindo, A., Cervantes-Cisneros, D.E., Aguilar, C.N., Fernandes, B.D., and Ruiz, H.A., 2018. Microalgal biomass pretreatment for bioethanol production: a review. Biofuel Research Journal. Vol 17. 780-791

Wang, L., and Waller, C.L., 2006. Recent advances in extraction of nutraceuticals from plants. Trends Food Science Technology. Vol 17. 300-312. 